\title{
The Brown Revolution
}

No longer number two.

\section{Norman Spinrad}

Your Majesty; members of the Swedish Academy; fellow Nobel laureates; ladies, gentlemen and others, including former sceptics and tormentors - while convention and politesse would have me falsely protest my unworthiness to receive these two Nobel prizes for the same so-called discovery, receiving the Nobels for biology and for peace at the same time is hardly conducive to false modesty. Nor, after what I have had to endure in ridicule to finally stand here before you, am I in a particularly polite mood.

After all, even after the Brown Revolution has rescued the world economy from its energy crisis and the biosphere from the global warming crisis, that which has saved global civilization and indeed life on Earth itself, still cannot fly the public banner of its own true name. And I, who championed its cause, am still a victim of ridicule in odious cartoons and toilet graffiti, and will no doubt be even now denigrated as the winner of the Nobel Prize for Scatology in the popular yellow press.

Very well then! Let my twin Nobels combine under that glorious Brown Banner that I have borne to this victory! Stand and salute the saviour of the planet! The noble brown substance that has replaced petroleum and coal to become the basic abundant energy source of our triumphant global civilization!

Two hundred and fifty trillion kilos of it produced per annum by man and beast at the very least! Converted to over 45 trillion cubic metres of methane, the energy equivalent of more than the world's yearly oil production at its long bygone and unlamented peak! Free food as a by-product! Every year, forever, as long as the grasses grow and the rivers flow and it flows downhill through the food chain with them!

Captured from every retooled toilet in the world; from every modernized closedcircuit pigpen and cattle feed-lot, chicken coop and zoo! The methane brewed out of it with simple solar collectors and panels heating the great stills and generating abundant electricity to charge our hydrogen fuel cells, cars and trucks; to power our industry, light our homes and our cities!

And this methane, not burned in the open air, poisoning it with photochemical smog and raising the temperature of the planet with greenhouse gases, but confined to sealed, closed-loop generators, recycling the carbon dioxide from its combustion into carbohydrates to feed the hungry via sunlight, water and artificial photosynthesis; as the biomass of this

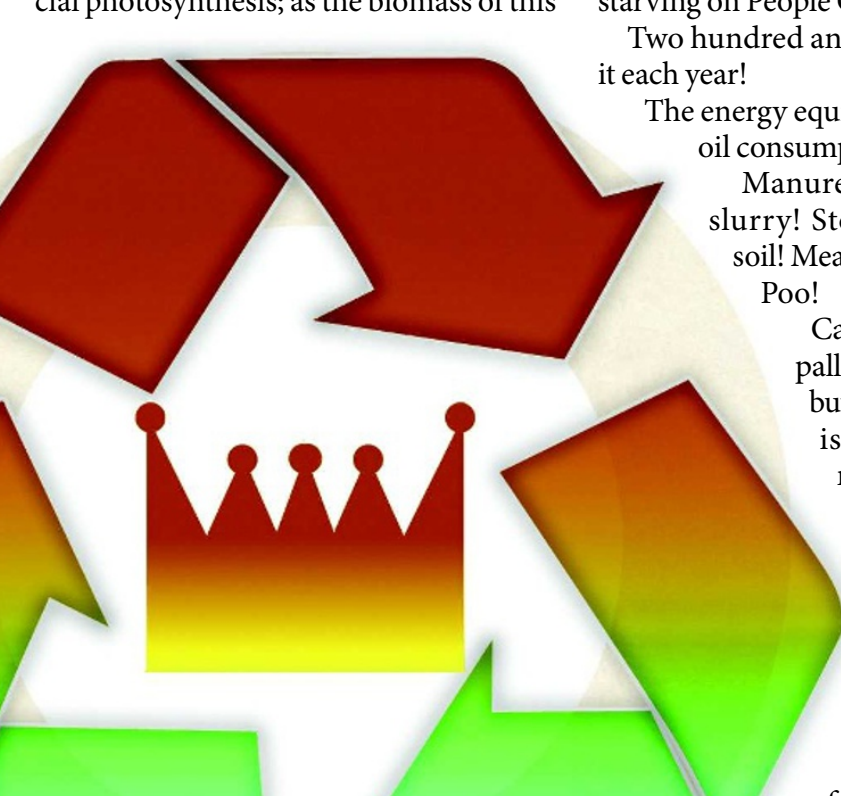

Yet we flushed it down our toilets; we dumped it into the seas; we let it pour into our rivers and pile up in feed-lot lagoons to spread disease and stink; we burned it in the open air and held our noses; we spent billions and billions throwing it away, or trying to; and all the while we were wasting the eternally renewable resource that has now, at last, become the energy source of global civilization, and allowed us to halt the greenhouse warming and feed the starving on People Chow.

Two hundred and fifty trillion kilos of

energy equivalent of a peak year's 岩 Manure! Dung! Crap! Fecal urry! Stools! Excreta! Night oil! Meadow-muffins! Doody! Poo

Call it by its hundreds of pallid euphemistic aliases, but call it also what it truly is, the long-despised, mocked, disdained substance we all produce each and every day of our lives, along with every animal we feed upon and many that we don't, that has become that which fuels the transformational machineries of the first human civilization to have freed itself from burning nonrenewable fossil fuels.

The sovereign substance of our glorious post-petroleum age!

Here in this most hallowed hall of planet has always done for just about as long as it has had one.

Oh yes, after having championed its cause and saved the world from its own stupidity at the cost of making myself a laughing stock in the process, the only modesty that I am in any mood to proclaim here today, before this august company, is that I invented nothing that the biosphere wasn't doing quite well by itself until industrial civilization turned up its nose at the obviously natural and the naturally obvious, and broke the natural cycle.

Sunlight, water and carbon dioxide into carbohydrates via photosynthesis, carbohydrates fuelling animal life, animal life releasing carbon dioxide out one end and water and fecal fecundity out the others; and so it goes. science and culture of our species let us finally speak it plain.

As you have crowned me with the golden wreath of the Nobel laureate, so do I now crown the Sun King of our glorious Brown Revolution with his true name before you!

Honour him!

Praise him!

Say it openly at long last!

All hail King Shit!

Norman Spinrad is the author of around 60 stories; more than 20 novels, including Bug Jack Barron, Pictures at Eleven, Greenhouse Summer and The Druid King; the classic Star Trek episode 'The Doomsday Machine'; and many other things. His most recent book is Mexica, the true story of Cortes's conquest of Mexico. 